\title{
Evaluating the soil quality of newly created farmland in the hilly and gully region on the Loess Plateau, China
}

\author{
CHEN Yiping ${ }^{1}$, WU Junhua ${ }^{1,2}$, WANG Hong ${ }^{1,2}$, MA Jifu ${ }^{1,2}$, SU Cuicui ${ }^{1,2}$, \\ WANG Kaibo ${ }^{1}$, WANG Yi ${ }^{1}$ \\ 1. State Key Laboratory of Loess and Quaternary Geology, Institute of Earth Environment, CAS, Xi'an 710061, \\ China; \\ 2. University of the Chinese Academy of Sciences, Beijing 100049, China
}

\begin{abstract}
In order to better understand the quality of newly created farmland (NF) as well as slope and check-dam farmland (CF) soil quality, two typical traditional farmland areas within the hilly and gully region of Chinese Loess Plateau were selected as controls in this analysis. The results of this study initially reveal that $\mathrm{pH}$ values for slope farmland (SF) and CF were significantly lower $(P<0.05)$ than those for NF and that SF values were always greater than those of their CF counterparts. At the same time, cation exchange capacity (CEC) and soil organic matter (SOM) occurred in the following size-decreasing sequence, i.e., CF, SF, and NF. Data also show that long-term planting has resulted in increases in total nitrogen (N), available $N$, total phosphorus $(P)$, available $P$, total potassium $(K)$ and available $K$ and has also enhanced concentrations of soil copper $(\mathrm{Cu})$, zinc $(\mathrm{Zn})$, iron $(\mathrm{Fe})$, and manganese $(\mathrm{Mg})$ as well as soil cadmium ( $\mathrm{Ca})$, lead $(\mathrm{Pb})$, chromium $(\mathrm{Cr})$, and mercury $(\mathrm{Hg})$. These latter elements occur in the concentration sequence of SF $>$ CF $>$ NF. Overall, results indicate that long-term planting negatively impacts soil health because of the accumulation of toxic heavy metals. This means that farmland planted over longer timescales needs to lie fallow to enable it to rehabilitate while NF requires the addition of organic matter as well as rotational utilization in order to facilitate the development of green agriculture.
\end{abstract}

Keywords: Loess Plateau; land use; soil quality; heavy metals

\section{Introduction}

The Loess Plateau covers approximately $62.4 \times 10^{4} \mathrm{~km}^{2}$ within China and comprises one of the most severe regions for soil erosion globally because of numerous gullies. The dominant form of agricultural farmland in this region is found on slopes less than $15^{\circ}$, encompassing $56.3 \%$ of the total on the plateau. A second abundant form of farmland is of a check-dam type, the most widespread structures used for controlling soil and water loss in this region, which encompass about $9 \%$ of the overall total. Check-dam farming is, however, responsible

Received: 2018-07-11 Accepted: 2018-12-15

Foundation: National Key Research and Development Program of China, No.2017YFD0800500

Author: Chen Yiping (1968-), Professor, specialized in environmental biology science and ecological process management. E-mail: lifesci@ieecas.cn 
for $20.5 \%$ of the total food production derived from the hilly and gully region (Chen et al., 2015; Liu et al., 2018).

The Chinese government implemented the Grain for Green (GFG) project in 1999 in order to reduce soil erosion, the largest vegetation ecological restoration program put in place since the founding of the People's Republic of China in 1949. Vegetation coverage on the Loess Plateau has greatly increased from $31.6 \%$ in 1999 to $59.6 \%$ in 2013 (Wang et al., 2011). Regional soil erosion has therefore been effectively reduced and annual sediment discharge into the Yellow River declined to $1.73 \mathrm{Gt}$ in 2013, close to primordial agricultural period levels (Chen et al., 2015). This largest vegetation restoration program also resulted in a grain deficit in partial regions on the Loess Plateau because this area exceeded the $105 \%$ of the upper limited area set by the GFG program (2.36 million ha) in 2008. As a result, 4.83 million ha of cropland was converted to forest and grassland on the Loess Plateau between 2000 and 2008, which doubled the limitation area for the GFG Program (Tang et al., 1998; Lu et al., 2012).

Liu et al. (2015) analyzed the benefits of useful agricultural productivity to meet the food supply needs of an expanding population. In order to address this contradiction between population and farmland shortages, the Chinese government implemented a program entitled 'Filling gullies to create farmland on the Loess Plateau' within the city of Yan'an on the Loess Plateau hilly and gully region in Shaanxi Province. This area within northern China includes $12.68 \%$ of the Loess Plateau area. Around 800 million USD dollars were invested in this project which created 333 million hectares of farmland between 2013 and 2017 (He, 2015; Liu et al., 2015). This approach, filling gullies to create farmland, involves the removal of soil from surrounding hills and then using this to infill channels. The flat fields created within these channels are then used for cultivation and ultimately increase the area of farmland on the Loess Plateau.

The completion of this gully filling project is one desirable outcome for regional sustainable development. It is clear that soil fertility plays a key role in both the growth of crops and their productivity. At the same time, however, little information is currently available about whether the fertility of new farmland will meet the needs for crop growth. In order to assess this outstanding question, a series of soil samples were collected from newly created (NF), slope (SF), and check-dam (CF) farmland and a range of physical and chemical parameters (i.e., $\mathrm{pH}$, cation exchange capacity (CEC), organic matter content, concentrations of total nitrogen $(\mathrm{N})$, available $\mathrm{N}$, total phosphorus $(\mathrm{P})$, available $\mathrm{P}$, total potassium $(\mathrm{K})$, and available $\mathrm{K}$ as well as heavy metals were measured in order to evaluate both the quality of NF and agricultural sustainability. Typical and primary farmland types (i.e., SF and CF lands) were selected as comparative samples.

\section{Materials and methods}

\subsection{Study area and sample site}

The soil samples evaluated in this study were collected from within the Liangjiahe $\left(110^{\circ} 43^{\prime} \mathrm{E}, 36^{\circ} 50^{\prime} \mathrm{N}\right)$ and Nangou watersheds $\left(109^{\circ} 17^{\prime} \mathrm{E}, 36^{\circ} 35^{\prime} \mathrm{N}\right)$, examples of typical hilly and gully regions on the Loess Plateau (Figure 1). These watersheds encompass the towns of Wen'anyi and Gaoqiao, respectively, within the city of Yan'an in Shaanxi Province. The av- 
erage annual temperature in this region ranges between $8.5^{\circ} \mathrm{C}$ and $9.5^{\circ} \mathrm{C}$, accumulated temperature (greater than or equal to $10^{\circ} \mathrm{C}$ ) ranges between $3100^{\circ} \mathrm{C}$ and $3300^{\circ} \mathrm{C}$, the frost-free period ranges between 162 days and 190 days, and average annual precipitation ranges between $520 \mathrm{~mm}$ and $550 \mathrm{~mm}$, all indicating a warm-temperate, arid and semi-arid climate zone (Zhang et al., 2016). Almost $70 \%$ of regional precipitation is concentrated in summer months when there is a high probability of heavy rains, floods, and droughts (Zhou et al., 1997).

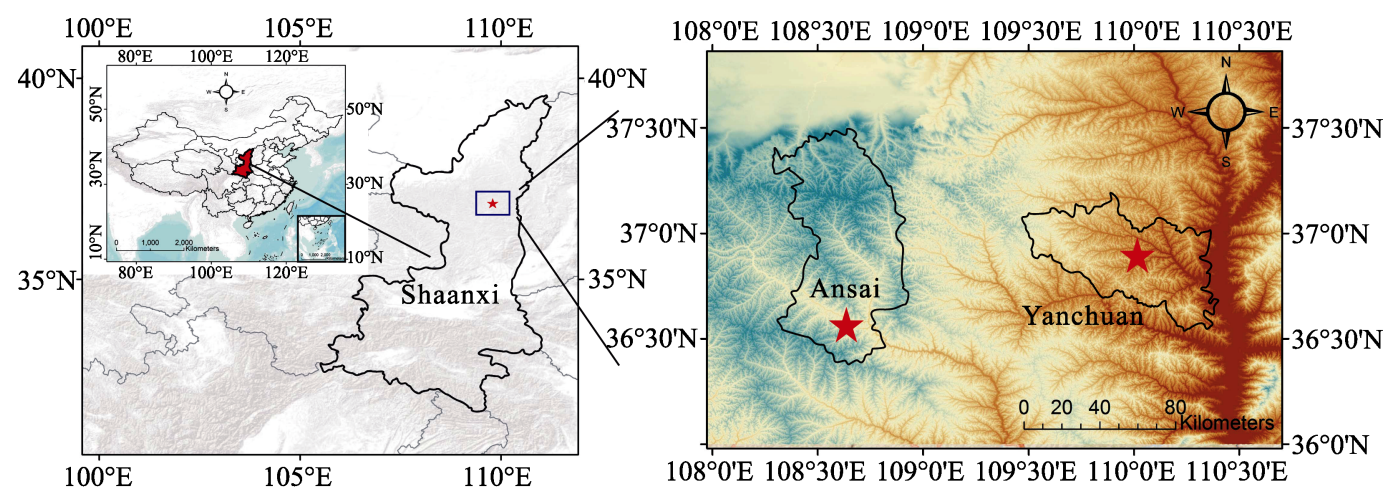

Figure 1 Maps showing the sample collection site. The five-pointed star denotes the sampling sites within Shaanxi Province, China.

Nine sample plots of $10 \mathrm{~m} \times 10 \mathrm{~m}$ each were selected from NF, SF, and CF regions, respectively. Specifically, NF areas within the Liangjiahe and Nangou watersheds were created in 2015 and have subsequently not been cultivated, while CF areas were implemented in the 1970s, and SF areas have been cultivated for more than 40 years. Maize (Zea mays L.) and potato (Solanum tuberosum L.) are cultivated extensively in both SF and CF areas. A total of five sample points were selected in each case using the 'diagonal' method during winter 2017; plough layer soil was collected from the surface to a depth of $20 \mathrm{~cm}$ and was mixed evenly before approximately $1 \mathrm{~kg}$ of loess was placed in polythene bags and brought to the laboratory for analysis. The soil type within these sampling regions is Huangmian Soil (Calcaric Cambisols, FAO) developed from loess parent material.

\subsection{Sample analysis}

Composite soil samples were sieved through a $2 \mathrm{~mm}$ nylon griddle to completely remove sundries, pebbles, roots, and litter before being air dried at room temperature. Subsamples of less than $2 \mathrm{~mm}$ air-dried soil were again ground to pass through $0.149 \mathrm{~mm}, 0.25 \mathrm{~mm}$, and $1.00 \mathrm{~mm}$ nylon sieves for further soil chemical analyses. The fraction less than $1.00 \mathrm{~mm}$ in size was used for soil $\mathrm{pH}$ as well as available $\mathrm{N}, \mathrm{P}, \mathrm{K}$, and trace element analyses. The fraction less than $0.25 \mathrm{~mm}$ in size was then also used for soil organic matter as well as total $\mathrm{N}, \mathrm{P}$, $\mathrm{K}$, and soil CEC capacity analyses, while the fraction less than $0.149 \mathrm{~mm}$ in size was used for total trace elements and heavy metal analyses.

Soil $\mathrm{pH}$ values were determined using the potential method (i.e., soil:water ratio 1:2.5) (GB7859-1987), while organic matter content was determined via hot oxidation with potassium dichromate and sulfuric acid (Yeomans et al., 1988). Soil total N and P contents were 
determined using the Kjeldahl digestion procedure (Bremner et al., 1972) and molybdenum antimony blue colorimetry (Murphy et al., 1962), respectively, while total K was determined using the $\mathrm{HF}-\mathrm{HClO}_{4}$ digestion method (Jackson, 1969). The amount of available $\mathrm{N}$ was released and transformed to $\mathrm{NH}_{3}$ using $1.07 \mathrm{M} \mathrm{NaOH}$ and $\mathrm{FeSO}_{4}$ powder at $40^{\circ} \mathrm{C}$ for $24 \mathrm{~h}$, and then absorbed with $2 \%(\mathrm{w} / \mathrm{v}) \mathrm{H}_{3} \mathrm{BO}_{3}$, and finally titrated with $0.005 \mathrm{M} \mathrm{H}_{2} \mathrm{SO}_{4}(\mathrm{Lu}, 2000)$. The amounts of available phosphorus and potassium were then determined by extracting samples with $0.5 \mathrm{M} \mathrm{NaHCO}_{3}(\mathrm{pH}=8.5)$ at a solution:solid ratio of 20:1 for 30 minutes (Olsen et al., 1982) and $0.2 \mathrm{M}$ cold $\mathrm{HNO}_{3}$ at a solution:solid ratio of 20:1 for 30 minutes (Bao, 2002), respectively. Soil CEC was measured following soil treatment with NaOAc $(\mathrm{pH}=8.2)$ and NH4OAc solutions ( $\mathrm{pH}=7.0)(\mathrm{Lu}, 2000)$.

Values for available iron $(\mathrm{Fe})$, manganese $(\mathrm{Mn})$, zinc $(\mathrm{Zn})$, and copper $(\mathrm{Cu})$ in soils were determined using the diethylenetriaminepentaacetic acid (DTPA) micronutrient extraction method (Lindsay et al., 1978). In order to determine contents of total $\mathrm{Fe}, \mathrm{Mn}, \mathrm{Zn}, \mathrm{Cu}$, chromium $(\mathrm{Cr})$, cadmium $(\mathrm{Cd})$, lead $(\mathrm{Pb})$, and mercury $(\mathrm{Hg})$ in soils, samples were digested with a typical concentrated acid mixture $\left(\mathrm{HCl}-\mathrm{HNO}_{3}-\mathrm{HF}-\mathrm{HClO}_{4}\right)(\mathrm{Zheng}$ et al., 2016) and metal concentrations were analyzed using atomic absorption spectroscopy (AAS; ZEEnit 700 P, Analytik Jena, Germany). Concentrations of $\mathrm{Fe}, \mathrm{Cu}, \mathrm{Zn}, \mathrm{Mn}$, and $\mathrm{Cr}$ were measured using the AAS air acetylene flame method applying an electrically modulated deuterium-HCL background correction. Hydride-forming $\mathrm{Hg}$ elements were measured using the AAS HS55 Hydride System, while concentrations of $\mathrm{Pb}$ and $\mathrm{Cd}$ were measured using the AAS graphite furnace coupled with a MPE 60 graphite autosampler, applying two-field mode Zeeman effects background correction. All metal concentrations were tested three times in this study and expressed in micrograms per gram on a dry weight basis $\left(\mathrm{mg} \cdot \mathrm{kg}^{-1} \mathrm{dw}\right)$.

\subsection{Statistical analysis}

One-way analysis of variance was used to determine the effects of land use on soil quality indicators, while the least significant difference (LSD) method was applied for multiple comparisons. All statistical analyses were performed using the software SPSS 20.0 (IBM SPSS Statistics, IBM Corp., USA), and a significance level $P<0.05$ was applied unless stated otherwise.

\section{Results}

\subsection{Soil pH, CEC, and organic matter}

The results of this analysis reveal that different types of farmland are characterized by a range of $\mathrm{pH}$ values (Figure 2). Data show that $\mathrm{pH}$ values for loess were significantly higher than the national average values $(\mathrm{pH} \approx 6.8)$ from a second soil survey (1979-1983), while compared with NF, $\mathrm{pH}$ values for SF and $\mathrm{CF}$ were significantly lower $(P<0.05)$ than those for

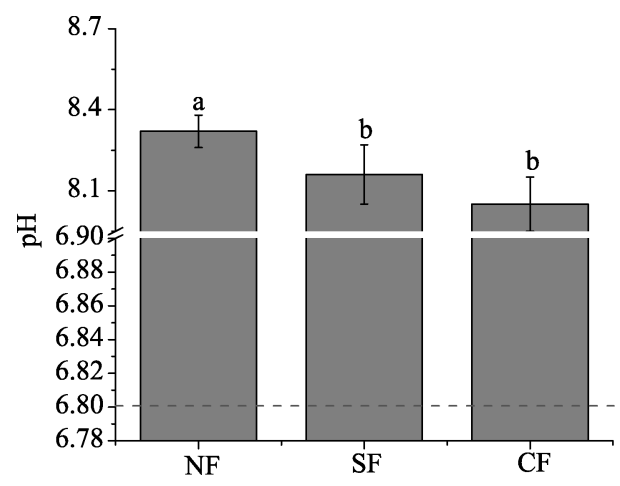

Figure 2 Comparisons between soil $\mathrm{pH}$ values in three loess types. Bars (means values \pm SD from six independent experiments) with different letters are significantly different at the 0.05 level $(n=6)$ based on LSD multiple comparisons. The dotted line denotes soil pH background levels (1979-1983). 
$\mathrm{NF}$ but for $\mathrm{SF} \mathrm{pH}$ values were greater than those recorded for $\mathrm{CF}$ soils.

The data presented in Figure 3 highlight changes in CEC (Figure 3a) and organic matter content (Figure $3 b$ ) in the different farmland types. The CEC size sequence recovered in this analysis (from largest-to-smallest) was CF, SF, and NF; differences between these three types were statistically significant $(P<0.05)$ (Figure 3a). Indeed, compared with NF samples, long-term planting has resulted in an increase in soil organic matter concentration (Figure 3b). The organic matter order recovered here (from largest-to-smallest) was CF, SF, and NF; data show that the NF content is lower than values seen in nine grade standards from Shaanxi Province (less than $\left.6.00 \mathrm{~g} \cdot \mathrm{kg}^{-1}\right)(\mathrm{Guo}, 1992)$ and therefore extremely deficient and unfavorable for crop growth and development.
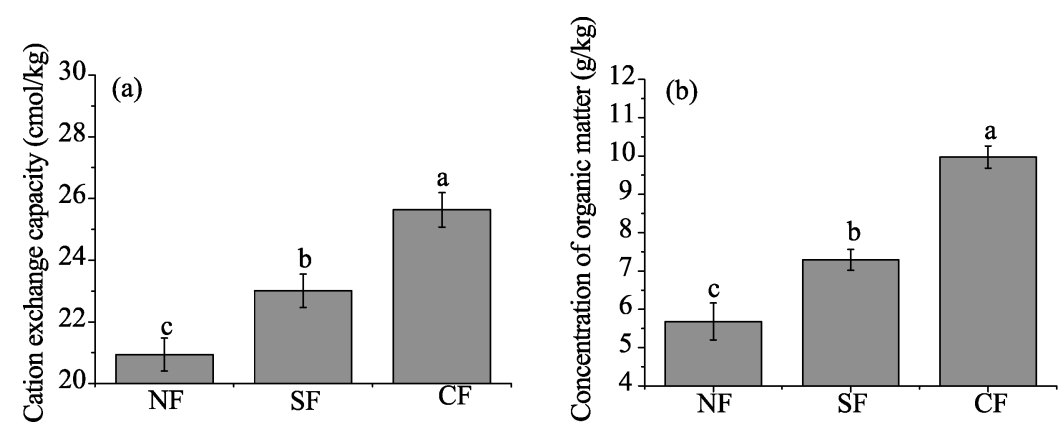

Figure 3 Comparisons between concentrations of soil CEC (a) and organic matter (b) in three types of loess soils. Bars (means values \pm SD from three independent experiments for CEC or six independent experiments for organic matter) with different letters are significantly different at the 0.05 level based on LSD multiple comparisons.

\subsection{Soil macro elements}

The data presented in Figure 4 illustrates changes in macroelement content within different types of farmland. Results show that compared with NF values, long-term planting has resulted in increases in total (Figure 4a) and available N (Figure 4b) as well as total (Figure 4c) and available P (Figure 4d), and total (Figure 4e) and available K (Figure 4f) concentrations. The order of change recovered in concentrations of total and available $\mathrm{N}$ as well as total and available $\mathrm{K}$ (from largest-to-smallest) were CF, SF, and NF, while concentrations of total (greater than $0.6 \mathrm{~g} \cdot \mathrm{mg}^{-1}$ ) and available $\mathrm{N}$ (greater than $30 \mathrm{~g} \cdot \mathrm{mg}^{-1}$ ) were all below basic six grade criteria for national nutrient levels on NF. These data show that NF soils within this study are unhealthy even though these regions are characterized by abundant potassium, at higher levels than those required by loess criteria (i.e., greater than $6 \mathrm{mg} \cdot \mathrm{kg}^{-1}$ for total and greater than $50 \mathrm{mg} \cdot \mathrm{kg}^{-1}$ for available $\mathrm{K}$, respectively) (Guo, 1992). The concentration order of change for total and available P (from largest-to-smallest) was SF, CF, and NF; total and available $\mathrm{P}$ concentrations did not, however, attain necessary loess criteria in any sample (i.e., greater than $0.6 \mathrm{mg} \cdot \mathrm{kg}^{-1}$ and greater than $5 \mathrm{mg} \cdot \mathrm{kg}^{-1}$, respectively) (Guo, 1992).

\subsection{Soil microelements}

The data presented in Figures 5 and 6 show changes in microelement contents given different patterns of soil utilization. These results reveal that compared with NF (Figure 5), 

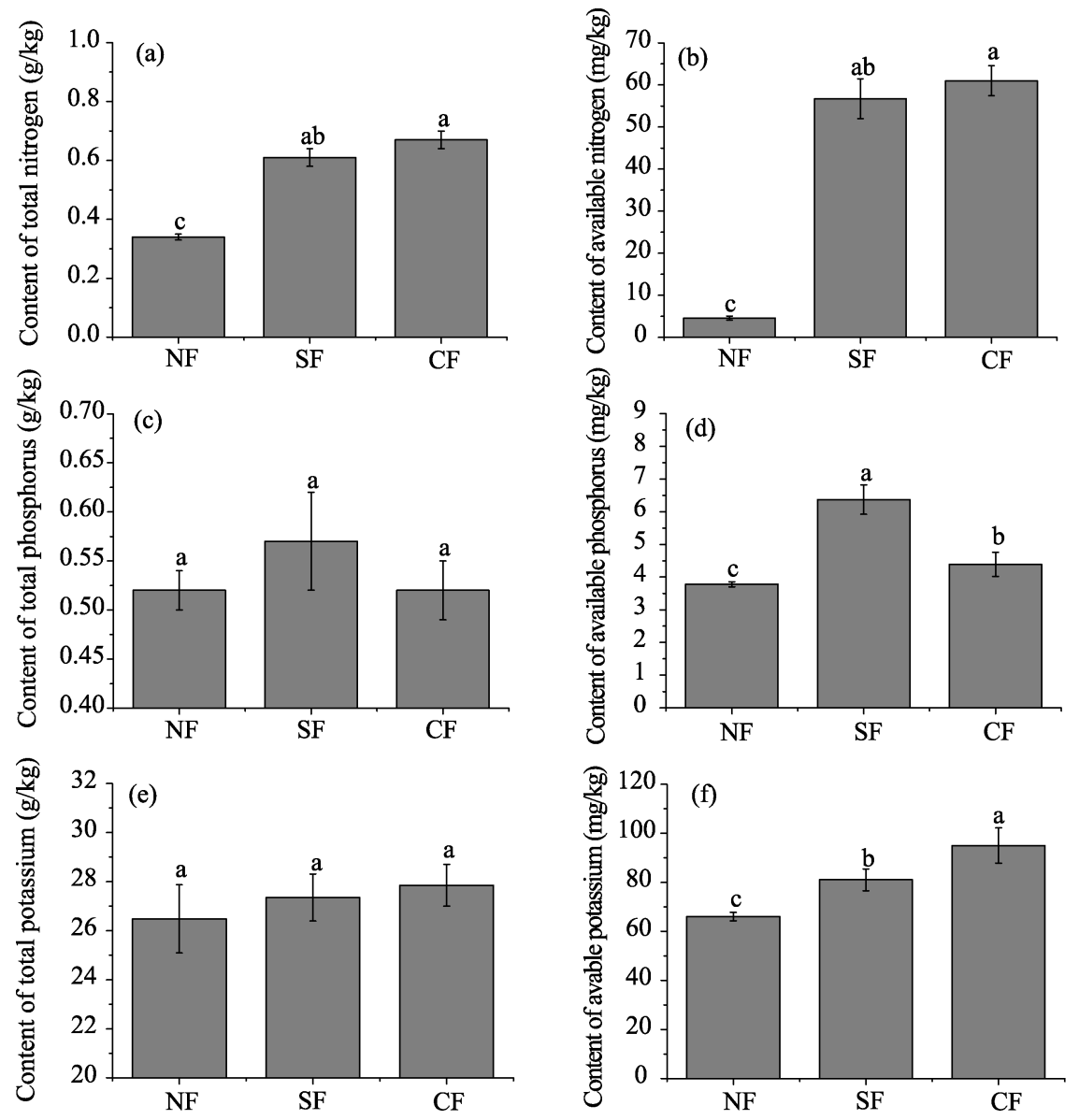

Figure 4 Comparisons between concentrations of total N (a), available N (b), total P (c), available P (d), total K (e) and available K (f) in three loess types. Bars (mean values \pm SD from six independent experiments) with different letters are significantly different at the 0.05 level $(n=6)$ based on LSD multiple comparisons.
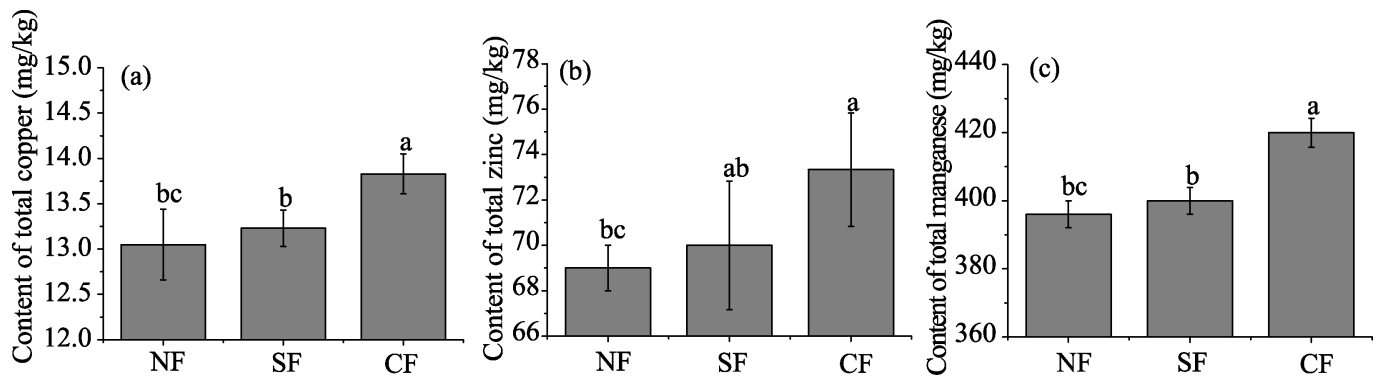

Figure 5 Comparisons between contents of total $\mathrm{Cu}$ (a), $\mathrm{Zn}(\mathrm{b})$, and $\mathrm{Mn}$ (c) in three loess types. Bars (mean values \pm SD from three independent experiments) with different letters are significantly different at the 0.05 level $(n=3)$ based on LSD multiple comparisons.

concentrations of total $\mathrm{Cu}$ (Figure 5a), Zn (Figure 5b), and $\mathrm{Mg}$ (Figure 5c) have all been enhanced by long-term planting $(P>0.05)$, an order of change from largest-to-smallest of $\mathrm{CF}, \mathrm{SF}$, and NF. It is also the case that NF long-term planting has enhanced concentrations of soil available $\mathrm{Cu}(P<0.05), \mathrm{Zn}(P<0.05)$, Fe $(P<0.05)$, and $\mathrm{Mg}(P<0.05)$ even though 

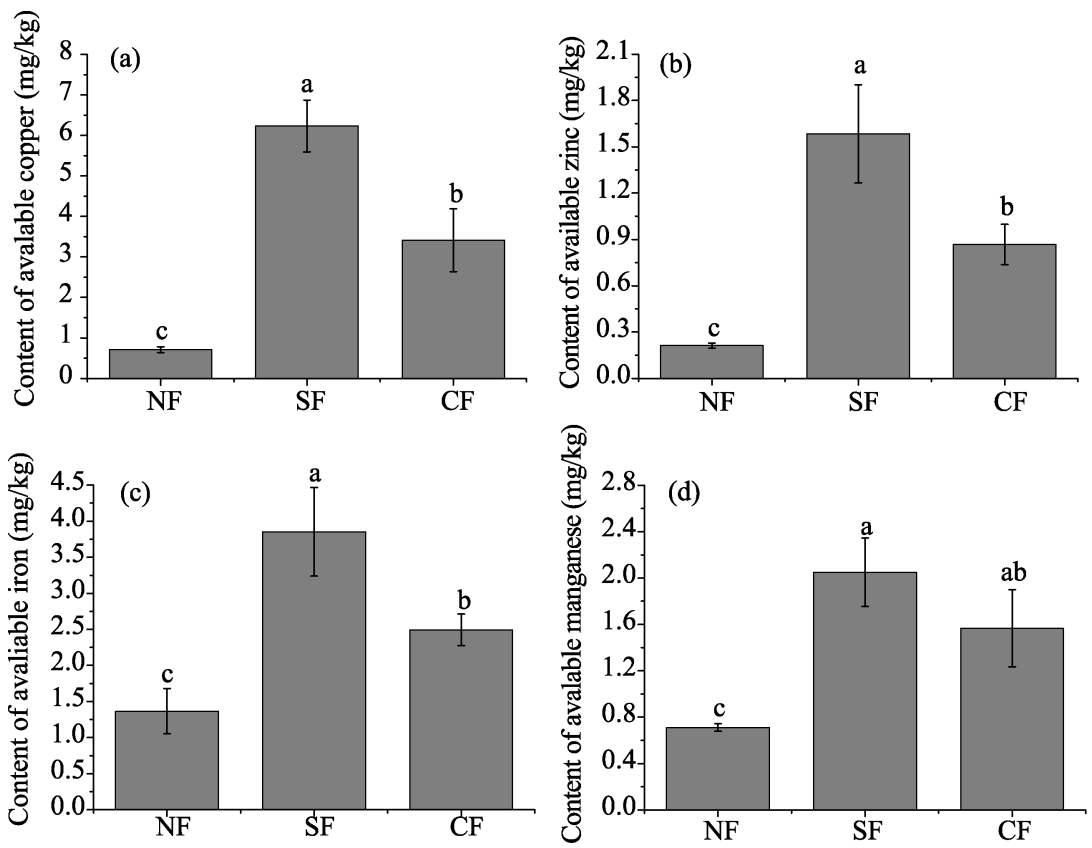

Figure 6 Comparisons between contents of soil available $\mathrm{Cu}(\mathrm{a}), \mathrm{Zn}(\mathrm{b}), \mathrm{Fe}(\mathrm{c})$, and $\mathrm{Mn}(\mathrm{d})$ in three loess types. Bars (mean values \pm SD from three independent experiments) with different letters are significantly different at the 0.05 level $(n=3)$ based on LSD multiple comparisons.

values for these parameters were significantly lower in CF cases than in SF $(P<0.05)$, with the exception of the latter element. Available Fe and $\mathrm{Mg}$ contents in all farmland types did not attain levels required by loess criteria, greater than $5.0 \mathrm{mg} \cdot \mathrm{kg}^{-1}$ and greater than 10 $\mathrm{mg} \cdot \mathrm{kg}^{-1}$, respectively. Values for available $\mathrm{Zn}$ content also did not reach the necessary level, greater than $1.0 \mathrm{mg} \cdot \mathrm{kg}^{-1}$, with the exception of the SF case (Guo, 1992).

\subsection{Soil toxic elements}

The data presented in Figure 7 highlight trends in concentrations of soil Cd (Figure 7a) as well as total $\mathrm{Pb}$ (Figure 7b), $\mathrm{Cr}$ (Figure 7c), and $\mathrm{Hg}$ (Figure 7d) in different farmland types. Although long-term planting has increased the concentrations of all these toxic elements in soil, the effects of different farmland types are significantly different with respect to $\mathrm{Cd}$ and $\mathrm{Pb}$ concentrations, in sequence from largest-to-smallest SF, CF, and NF. The concentration order for $\mathrm{Cr}$ and $\mathrm{Hg}$ from largest-to-smallest was $\mathrm{CF}$, SF, and $\mathrm{NF}$. Data show that $\mathrm{Hg}$ concentrations in all farmland types exceeded the safe background value of $0.06 \mathrm{mg} \cdot \mathrm{kg}^{-1}$ (Xue, 1986).

\section{Discussion}

\subsection{Loess pH values}

The physicochemical and biological properties of soils have always been influenced by $\mathrm{pH}$ values. Indeed, soil $\mathrm{pH}$ is well known to play a significant role in fertility formation and evolution (Brady et al., 1999; Aciego et al., 2008). Previous research performed as part of 

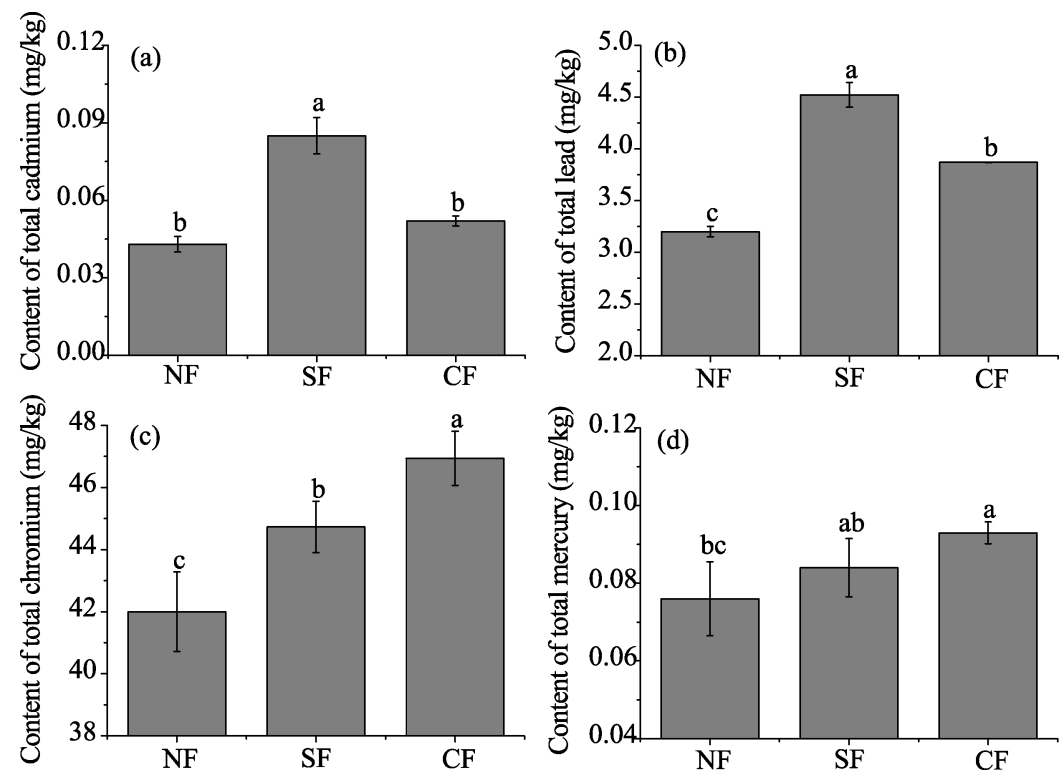

Figure 7 Comparisons between concentrations of total $\mathrm{Cd}(\mathrm{a}), \mathrm{Pb}(\mathrm{b}), \mathrm{Cr}(\mathrm{c})$, and $\mathrm{Hg}(\mathrm{d})$ in three loess types. Bars (mean values \pm SD from three independent experiments) with different letters are significantly different at the 0.05 level $(n=3)$ on the basis of LSD multiple comparisons.

the second soil survey (1979-1983) has shown that loess pH values for NF, SF and CF lands all tend to be significantly higher than the national average $(\mathrm{pH} \approx 6.8)$, being $22 \%, 20 \%$, and $18 \%$, respectively. It is also the case that long-term planting acts to significantly decrease loess $\mathrm{pH}$ values but there is nevertheless an insignificant difference between SF and CF lands in this analysis. In terms of plant growth, NF lands require amelioration via acidic comprehensive fertility because a neutral $\mathrm{pH}$ is advantageous to both crop growth and development; a range between $\mathrm{pH} 5.5$ and $\mathrm{pH} 6.5$ has been shown to be best for potato and tomato growth (Islam et al., 1980).

\subsection{Loess organic matter}

The quality and fertility of soils can be characterized on the basis of numerous basic chemical parameters, including CEC, organic matter, and total N. The first of these variables, CEC, is an indicator of soil quality and fertility; thus, a higher CEC concentration equates to better soil quality and fertility (Brady et al., 2002). The results of this analysis show that different farmland types have significantly different effects on CEC capacity $(P<0.05)$ (Figure 2a); results reveal a CEC size sequence from largest-to-smallest of $\mathrm{CF}, \mathrm{SF}$, and NF. The data suggest that the fertility of CF lands is better than that of their SF counterparts, while NF areas are the worst of the three loess types.

Organic matter content is the dominant index for assessing soil quality in agricultural practice (Bellamy et al., 2005). Long-term cultivation has resulted in an increase in the concentration of soil organic matter (Wang et al., 2015), from largest-to-smallest CF, SF, and NF. Soil CEC is closely correlated with $\mathrm{pH}$ values and SOM content (Caravaca et al., 1999; Von Oheimb et al., 2008); results show that CEC is negatively related to soil $\mathrm{pH}$ values ( $\mathrm{r}=$ $-0.579)$ and positively related to SOM $(\mathrm{r}=0.737)$, consistent with previous research (Qiu et 
al., 2010). Results show that soil organic matter content does not reach the necessary nine grade standard within Shaanxi Province (greater than $\left.6.00 \mathrm{~g} \cdot \mathrm{kg}^{-1}\right)(\mathrm{Guo}, 1992)$ for NF lands and is therefore extremely deficient and unfavorable for the growth and development of crops. Appropriate amounts of organic matter must therefore be added to NF lands and $\mathrm{pH}$ values must be decreased in order to increase both CEC capacity and soil quality.

\subsection{Loess macroelements}

Chemical elements play very important roles in plant growth and development. At the same time, however, different elements perform varied physiological functions within plant lifecycles and can be classified as either macroelements (e.g., N, P, and K), medium elements, (e.g., $\mathrm{Ca}, \mathrm{Mg}$, and $\mathrm{S}$ ), or trace elements (e.g., $\mathrm{Fe}, \mathrm{Mn}, \mathrm{Cu}, \mathrm{Zn}, \mathrm{Mo}$, and $\mathrm{Cl}$ ) according to vital growth requirements (Kalavrouziotis et al., 2008; Li et al., 2010).

$\mathrm{N}$ retention and supply are thought to be influenced by soil organic matter (Brubaker et al., 1993). This element is the key raw material for amino acids and also performs a very important function in soil fertility. The results of this study show that the concentration of total $\mathrm{N}$ was insignificantly higher $(P<0.05)$ in both SF and CF lands compared to NF lands. Available $\mathrm{N}$ is directly absorbed by crops and influences both growth and yield (Macdonald et al., 2009); data show that this element occurs at significantly higher levels in both SF and $\mathrm{CF}$ lands compared to NF areas. It is also the case that fertility in SF and CF cases tends to be higher in terms of soil organic matter and $\mathrm{N}$ when compared to NF situations. This result implies that NF lands require a supply of both soil organic matter and $\mathrm{N}$.

The element $\mathrm{P}$ is an important nutrient necessary for both plant growth and development. However, although soil contains a large proportion of total $\mathrm{P}$, just a relatively small component is immediately available to plants (Richardson et al., 2009); this means that ensuring a suitable volume of this element in soils is critical for both crop growth and agricultural productivity. The results of this study also reveal that the concentration change order of total and available phosphorus was SF, CF, and NF (from largest-to-smallest) but that total phosphorus concentration did not reach the required loess criterion level in all cases (greater than $0.6 \mathrm{mg} \cdot \mathrm{kg}^{-1}$ ). As this was also the case for available phosphorus concentrations (greater than $\left.5 \mathrm{mg} \cdot \mathrm{kg}^{-1}\right)(\mathrm{Guo}, 1992)$ it is clear that deficiencies decrease crop yields as available $\mathrm{P}$ is almost universally required to maintain production (Sundara et al., 2002). The results of this analysis therefore suggest that phosphorus fertilization should be carried out to improve crop yields on NF lands.

The element $\mathrm{K}$ is also key for plant growth and development; the presence of this metal enhances saccharide transport ratios and photosynthesis in natural ecosystems (Tripler et al., 2006), while the presence of soil available $\mathrm{K}$ trapped between interlayers of clay minerals is an important resource for plant growth in many soils (Mengel et al., 1993). The results of this analysis demonstrate that long-term planting enhances concentrations of both total and available K; indeed, available contents of this metal equaled (or exceeded) loess criteria in all cases (greater than $\left.50 \mathrm{mg} \cdot \mathrm{kg}^{-1}\right)(\mathrm{Guo}, 1992)$. It is therefore clear that NF lands do not require the addition of this element.

\subsection{Loess microelements}

Trace micronutrient elements in field crops (e.g., $\mathrm{Fe}, \mathrm{Mn}, \mathrm{Cu}$ and $\mathrm{Zn}$ ) are essential for 
growth and development although concentrations at one in a thousand levels are required (Zou et al., 2008). Earlier research has estimated (Sillanpää, 1982, 1990) that agricultural soils globally are $49 \%$ deficient in $\mathrm{Zn}, 14 \%$ deficient in $\mathrm{Cu}, 10 \%$ deficient in $\mathrm{Mn}$, and 3\% deficient in Fe. The results of this analysis also suggest that concentrations of total $\mathrm{Cu}$ (Figure 5a), $\mathrm{Zn}$ (Figure 5b), and Mn (Figure 5c) have been enhanced by long-term planting $(P>$ 0.05 ), from largest-to-smallest change in the order CF, SF, and NF. This result implies that NF lands require the addition of reasonable levels of supplementary trace micronutrients.

Availability in this context can be defined as the quantity of a soil nutrient that is accessible to plant roots over a useful time period such as one growing season (White et al., 1999). Crop roots can also absorb micronutrients directly from soils in solution, which results in a decrease in the total pool available. Previous research has shown that available concentrations of $\mathrm{Fe}, \mathrm{Mn}, \mathrm{Cu}$, and $\mathrm{Zn}$ are related to plant growth responses to micronutrients (White et al., 1999); this means that deficiencies in available micronutrients can lead to physiological sickness. Long-term planting enhances the concentrations of soil available $\mathrm{Cu}(P<0.05), \mathrm{Zn}$ $(P<0.05)$, Fe $(P<0.05)$, and $\mathrm{Mn}(P<0.05)$. However, available contents of Fe and $\mathrm{Mn}$ in all farmland types assessed here did not attain necessary loess criteria values greater than 5.0 $\mathrm{mg} \cdot \mathrm{kg}^{-1}$ and greater than $10 \mathrm{mg} \cdot \mathrm{kg}^{-1}$, respectively. This was also the case for available $\mathrm{Zn}$ (criterion greater than $1.0 \mathrm{mg} \cdot \mathrm{kg}^{-1}$ ), with the exception of SF lands (Guo, 1992). It is therefore clear that NF lands will require the addition of fertilizer or micronutrient supplements for plant growth because of low $\mathrm{Fe}, \mathrm{Mn}, \mathrm{Cu}$, and $\mathrm{Zn}$ levels.

\subsection{Non-essential loess elements}

The pollution of soils with heavy metals has become a severe problem in many parts of the world (Facchinelli et al., 2001; Solgi et al., 2012). As a direct result of rapid socioeconomic development over recent decades, soil pollution by heavy metals has become both serious and widespread in China because of the overuse of chemical fertilizers (Chen et al., 1999; Wang et al., 2001). Although some heavy metals are present in soils, additional contributions also come from anthropogenic activities including agriculture, urbanization, industrialization, and mining (Facchinelli et al., 2001). This kind of pollution not only degrades soil quality and results in a decrease in crop growth, but threatens human health via the food chain (Wang et al., 2001; Nabulo et al., 2010; Dong et al., 2011). The elements $\mathrm{Pb}, \mathrm{Cd}, \mathrm{Cr}$, and $\mathrm{Hg}$ are the most toxic, while the main sources of heavy metals in soil are from various agrochemicals, fertilizers, pesticides, and atmospheric deposition (Berthelsen et al., 1995; Gray et al., 2003; Huang et al., 2007). They influence crop growth and damage soil ecosystem health. Although concentrations of $\mathrm{Pb}, \mathrm{Cd}, \mathrm{Cr}$, and $\mathrm{Hg}$ do not reach ecological risk levels in any of the land types studied here, $\mathrm{Cd}$ concentrations did exceed criteria in all cases (less than, or equal to, $1 \mathrm{mg} \cdot \mathrm{kg}^{-1}$ ) (Xue, 1986). The results of this analysis are therefore particularly relevant to SF and CF lands, while NF areas appear to be the most suitable for green agriculture.

\section{Conclusions}

The results of this study show that different farmland types encompass different nutrient levels in the context of loess physicochemical parameters. In the first place, NF lands tend to have higher $\mathrm{pH}$ values which should be decreased artificially, while the soil organic matter 
content of these areas is lower than the nine grade standard in Shaanxi Province (less than $\left.6.00 \mathrm{~g} \cdot \mathrm{kg}^{-1}\right)$. These lands are therefore extremely deficient and unfavorable for crop growth and development. The data show that concentrations of total (greater than $0.6 \mathrm{~g} \cdot \mathrm{mg}^{-1}$ ) and available $\mathrm{N}$ (greater than $30 \mathrm{~g} \cdot \mathrm{mg}^{-1}$ ) fall below the basic line of six grade criteria for national nutrient levels in NF lands while at the same time this farmland contains abundant K. Total $\mathrm{P}$ concentrations do not attain loess criteria values in all soil samples (greater than 0.6 $\mathrm{mg} \cdot \mathrm{kg}^{-1}$ ) as is also the case for available concentrations of this element (greater than 5 $\mathrm{mg} \cdot \mathrm{kg}^{-1}$ ). The data also show that NF lands do tend to lack some useful microelements but contain some toxic components. The results of this study suggest that NF lands are currently unhealthy and require increases in fertility for effective agricultural practice. Results indicate that long-term planting is a risk to soil health because of the accumulation of toxic heavy metals. Long-term planting therefore also requires fallow and rehabilitation to ensure food security.

\section{References}

Aciego Pietri J C, Brookes P C, 2008. Relationships between soil pH and microbial properties in a UK arable soil. Soil Biology \& Biochemistry, 40(7): 1856-1861.

Bao S D, 2002. Soil Agricultural Chemical Analysis. Beijing: China Agricultural Press (in Chinese)

Bellamy P H, Loveland P J, Bradley R I et al., 2005. Carbon losses from all soils across England and Wales 1978-2003. Nature, 437(7056): 245-248.

Berthelsen B O, Steinnes E, Solberg W et al., 1995. Heavy-metal concentrations in plants in relation to atmospheric heavy-metal deposition. Journal of Environmental Quality, 24(5): 1018-1026.

Brady N C, Buckman H O, 1999. The nature and properties of soil. Journal of Range Management, 5(6): 333.

Brady N C, Weil R R, 2002. The Nature and Properties of Soil. 13th ed. Springer Netherlands.

Bremner J, Tabatabai M, 1972. Use of an ammonia electrode for determination of ammonium in kjeldahl analysis of soils1. Communications in Soil Science \& Plant Analysis, 3(2): 159-165.

Brubaker S C, Jones A J, Lewis D T et al., 1993. Soil properties associated with landscape position. Soil Science Society of America Journal, 57(1): 235-239.

Caravaca F, Lax A, Albaladejo J, 1999. Organic matter, nutrient contents and cation exchange capacity in fine fractions from semiarid calcareous soils. Geoderma, 93(4): 161-176.

Chen H M, Zheng C R, Tu C et al., 1999. Heavy metal pollution in soils in china: Status and countermeasures. Ambio, 28(2): 130-134.

Chen Y, Wang K, Lin Y et al., 2015. Balancing green and grain trade. Nature Geoscience, 8(10): 739-741.

He C X, 2015. The situation, characteristics and effect of the gully reclamation project in Yan'an. Journal of Earth Environment, 6(4): 255-260.

Dong J, Yang Q W, Sun L N et al., 2011. Assessing the concentration and potential dietary risk of heavy metals in vegetables at a $\mathrm{Pb} / \mathrm{Zn}$ mine site, China. Environmental Earth Sciences, 64(5): 1317-1321.

Facchinelli A, Sacchi E, Mallen L, 2001. Multivariate statistical and GIS-based approach to identify heavy metal sources in soils. Environmental Pollution, 114(3): 313-324.

Gray C, McLaren R, Roberts A, 2003. Atmospheric accessions of heavy metals to some New Zealand pastoral soils. The Science of The Total Environment, 305(1-3): 105-115.

Guo Z Y, 1992. Soil of Shaanxi. Beijing: Science Press (in Chinese).

Huang S S, Liao Q L, Hua M et al., 2007. Survey of heavy metal pollution and assessment of agricultural soil in Yangzhong District, Jiangsu Province, China. Chemosphere, 67(11): 2148-2155.

Islam A, Edwards D G, Asher C J, 1980. pH optima for crop growth: Results of a flowing solution culture experiment with 6 species. Plant and Soil, 54(3): 339-357.

Jackson M L, 1969. Soil Chemical Analysis: Advanced Course. University of Wisconsin, Madison, Wisconsin.

Kalavrouziotis I K, Robolas P, Koukoulakis P H et al., 2008. Effects of municipal reclaimed wastewater on the macro- and micro-elements status of soil and of brassica oleracea var. Italica, and b-oleracea var. Gemmifera. Agricultural Water Management, 95(4): 419-426.

Li J W, Richter D D, Mendoza A et al., 2010. Effects of land-use history on soil spatial heterogeneity of macroand trace elements in the southern piedmont USA. Geoderma, 156(2): 60-73.

Lindsay W L, Norvell W A, 1978. Development of a dtpa soil test for zinc, iron, manganese, and copper. Soil Science Society of America Journal, 42(3): 421-428. 
Liu Q, Wang Y, Zhang J et al., 2013. Filling gullies to create farmland on the Loess Plateau. Environmental Science \& Technology, 47(14): 7589-7590.

Liu Y S, Guo Y J, Li Y R et al., 2015. GIS-based effect assessment of soil erosion before and after gully land consolidation: A case study of Wangjiagou project region, Loess Plateau. Chinese Geographical Science, 25(2): 137-146.

Lu R K. 2000. Soil Analytical Methods of Agronomic Chemicals. Beijing: China Agricultural Science and Technology Press (in Chinese).

Lu Y, Fu B, Feng X et al., 2012. A policy-driven large scale ecological restoration: Quantifying ecosystem services changes in the Loess Plateau of China. PLoS One, 7(2): 31782.

Macdonald C A, Thomas N, Robinson L et al., 2009. Physiological, biochemical and molecular responses of the soil microbial community after afforestation of pastures with Pinus radiata. Soil Biology and Biochemistry, 41(8): 1642-1651.

Mengel K, Uhlenbecker K, 1993. Determination of available interlayer potassium and its uptake by ryegrass. Soil Science Society of America Journal, 57(3): 761-766.

Murphy J, Riley J P, 1962. A modified single solution method for the determination of phosphate in natural waters. Analytica Chimica Acta, 27: 31-36.

Nabulo G, Young S D, Black C R, 2010. Assessing risk to human health from tropical leafy vegetables grown on contaminated urban soils. Science of the Total Environment, 408(22): 5338-5351.

Olsen S, Sommers L, 1982. Methods of soil analysis. Part 2: Phosphorus methods of soil analysis. ASA Monograph, 9: 403-430.

Qiu L P, Zhang X C, Cheng J M et al., 2010. Effects of black locust (Robinia pseudoacacia) on soil properties in the loessial gully region of the Loess Plateau, China. Plant and Soil, 332(2): 207-217.

Richardson A E, Hocking P J, Simpson R J et al., 2009. Plant mechanisms to optimise access to soil phosphorus. Crop \& Pasture Science, 60(2): 124-143.

Sillanpää, M, 1982. Micronutrients and the nutrient status of soils: A global study. Soils Bulletin 48, FAO, Rome.

Sillanpää, M, 1990. Micronutrient assessment at country level: An international study. Soils Bulletin No. 63, FAO, Rome.

Solgi E, Esmailisari A, Riyahibakhtiari A et al., 2012. Soil contamination of metals in the three industrial estates, Arak, Iran. Bulletin of Environmental Contamination and Toxicology, 88(4): 634-638.

Sundara B, Natarajan V, Hari K, 2002. Influence of phosphorus solubilizing bacteria on the changes in soil available phosphorus and sugarcane and sugar yields. Field Crops Research, 77(1): 43-49.

Tang K L, Zhang K L, Lei A L, 1998. Critical slope gradient for compulsory abandonment of farmland on the hilly Loess Plateau. Chinese Science Bulletin, 43(5): 409-412.

Teng Y, Wu J, Lu S et al., 2014. Soil and soil environmental quality monitoring in China: A review. Environ. Int., 69: 177-199.

Tripler C E, Kaushal S S, Likens G E et al., 2006. Patterns in potassium dynamics in forest ecosystems. Ecology Letters, 9(4): 451-466.

Von Oheimb G, Hardtle W, Naumann P S et al., 2008. Long-term effects of historical heathland farming on soil properties of forest ecosystems. Forest Ecology and Management, 255(6): 1984-1993.

Wang F, Mu X, Li R et al., 2015. Co-evolution of soil and water conservation policy and human-environment linkages in the Yellow River Basin since 1949. Science of the Total Environment, 508: 166-177.

Wang Q, Dong Y, Cui Y et al., 2001. Instances of soil and crop heavy metal contamination in China. Soil and Sediment Contamination: An International Journal, 10(5): 497-510.

Wang X, Tang C, Baldock J A et al., 2015. Long-term effect of lime application on the chemical composition of soil organic carbon in acid soils varying in texture and liming history. Biology and Fertility of Soils, 52(3): 295-306.

Wang Y, Fu B, Chen L et al., 2011. Check dam in the Loess Plateau of China: Engineering for environmental services and food security. Environ. Sci. Technol., 45(24): 10298-10299.

White J G, Zasoski R J, 1999. Mapping soil micronutrients. Field Crops Research, 60(1): 11-26.

Xue Chengze, Xiao Ling, Wu Qianfeng et al., 1986. Study on the background value of ten elements in the main agricultural soil of Shaanxi Province. Journal of Northwest Sci-tech University of Agriculture and Forestry (Natural Science Edition), 14(3): 30-53 (in Chinese).

Yeomans J C, Bremner J M, 1988. A rapid and precise method for routine determination of organic carbon in soil 1. Communications in Soil Science \& Plant Analysis, 19(13): 1467-1476.

Zhang B Q, He C S, Burnham M et al., 2016. Evaluating the coupling effects of climate aridity and vegetation restoration on soil erosion over the Loess Plateau in China. Science of the Total Environment, 539: 436-449.

Zheng Y J, Chen Y P, Maltby L et al., 2016. Highway increases concentrations of toxic metals in giant panda habitat. Environ. Sci. Pollut. Res. Int., 23(21): 21262-21272.

Zhou Z S, Zheng S Q, Wu P T et al., 1997. The study on anti-scourability of soil in Loess Plateau. Research of Soil \& Water Conservation, 4(5): 47-58 (in Chinese). 